\title{
The Appeal to Tradition: Cultural Evolution and Logical Soundness
}

\author{
WILLIAM D. HARPINE University of Akron
}

Key Words: Tradition; appeal to tradition; fallacies; evolutionary epistemology; adaptation; environment; neo-Darwinian theory; culture; cultural change; Boyd, Robert; Campbell, Donald T.; Richerson, Peter J.; Toulmin, Stephen E.

\begin{abstract}
The Appeal to Tradition, often considered to be unsound, frequently reflects sophisticated adaptations to the environment. Once developed, these adaptations are often transmitted culturally rather than as reasoned argument, so that people may or may not be aware of why their traditions are wise. Tradition is more likely to be valid in a stable environment in which a wide range of variations have been available for past testing; however, traditions tend to become obsolete in a rapidly changing environment.
\end{abstract}

\section{Pascal Boyer states:}

An important feature of traditional practice is that, in most cases, the actors do not bother to justify or rationalise it. Typically, the anthropologist is told "we do this because we've always done so" or "because it must be so, otherwise it would not be proper" or "because the ancestors told us to do it", and this type of statement is certainly part of the specific intellectual climate of traditional institutions. This of course does not mean that traditional practice is without thyme or reason, but, more precisely, that traditional things seem to provide their own justification. (Boyer 11)

That is, the appeal to traditional wisdom may be sound even if the arguers are unable to offer a clear argument for their practices.

Fallacious appeal to tradition is common enough. At a church committee meeting I spoke for starting a youth choir. The appalled committee members referred to the "history" of the church, explained that we had never had a youth choir before, and changed the subject. That the church's youth program was falling apart was, to them, beside the point.

But, on the other hand, consider the world's most famous tradition. After his 1856 Grand Tour passed by the Hindu temple at Banares, New Yorker Robert Minturn remarked on the "inconveniently numerous and tame" cattle:

The bull is the most sacred animal in the Hindoo mythology. . . A Hindoo considers the slaughter of a bull or cow, as a greater crime than parricide; and in old times this offence was punished with death - a penalty that was long permitted to remain in force in some parts of India, by the Honourable Company... (Minturn 140).

Many India experts have argued, with considerable reference to evidence, that the traditional Indian practice is "irrational" (Harris, "Cultural Ecology" 51-52). Yet the tradition of not eating cows was rightand the thoroughly researched and carefully reasoned arguments wrong-even though for years no one really knew why.

Harris observed that the animals are fed on grass and thus do not compete with humans for grain. The cows give milk, which the people can drink long after the meat would be gone; dried cattle dung is carefully collected for fertilizer and fuel. Cattle are in demand as draft animals, which are perennially in short supply. And when the animals finally die, "untouchables" are often called to dispose of the carcass, using nearly every scrap. Harris concludes, in essence, that the starving population would starve sooner if they ate their cattle (Harris, "Cultural Ecology"; Harris, Cows 20-21; see also Nair 452-454). Is it a fallacy to 
appeal to the practices of traditional wisdom in the face of seemingly cogent, apparently persuasive arguments for change?" That is, can it be valid to allow more weight to tradition than to what would otherwise seem to be good reasons to change? The selection processes of cultural evolution, this essay argues, can give a better warranty for traditional practices than rational dispute about the issues. That is, everything that a people know and can figure out, other than what they know about the value of tradition in general, might show a practice or belief to be unwise, and yet to adhere to it can still be justified.

As the argument below explains, the appeal to traditional wisdom is of particular merit when (1) the environment has been stable for a long time, so that unwise variations can be gradually weeded out and (2) when the culture is well adapted and stable. Arguments against traditional wisdom should carry increased weight if they support (1) new variations not previously tested and discarded by the culture, or (2) variations that the culture has suppressed without testing or evaluation.

\section{The Limitations of Reason}

All decision making by argument introduces the chance of error (Boyd and Richerson, 128-130). Human beings can reason through complex problems but, given the complexity of the world and of social institutions, there is a good chance of miscalculating something. Any supposed illogic committed in relying on traditional wisdom must be balanced against these uncertainties, especially with respect to social institutions and practices. Not only can it be difficult to predict the consequences of change, but traditional practices often have unseen advantages.

Toulmin argues that "... given the short-term character of human foresight and calculation in the social realm, it is hard to see how any sort of conscious, deliberate, calculated human decisions could have brought effective social arrangements into existence in the first place" (Toulmin, "Human Adaptation" 183). Because of their complexity, ". . . even middle- and longer-term changes in social institutions and political arrangements can scarcely be accounted for convincingly as the results of straightforward rational choices" (Toulmin, "Human Adaptation" 183-184). Harris, pointing out that no one ever planned the modern world, comments:
.. the major processes of cultural evolu- tion do not bear witness to our kind's abili- ty to exert conscious, intelligent control over our species' destiny. This is a para- doxical finding in view of the fact that uniquely among organisms, our brains have "minds" that are aware of the process- ing of information, the making of choices, the planning of behavior, and the intention- al effort to achieve future goals. (Harris, Our Kind 494)

Among other examples, Harris points out how the automobile, developed to ease transportation, stimulated the wholesale reorganization of life in the industrialized nations. Who could have foreseen this (Harris, Our Kind 494-498)? If human societies work (as many apparently do, more or less), we need an explanation why they work-and the usual panegeric on the near-divine wisdom of the human animal won't quite do.

\section{Evolutionary Epistemology, Culture, and Tradition}

Some philosophers, influenced by Popper, study the evolution of knowledge in relationship to the natural world. Viewing intellectual variation and selection as analogous to neo-Darwinian theory, Toulmin finds the evolution of scientific ideas "similar to other "evolutionary" processes" (Toulmin, "Human Adaptation" 188; emphasis added). ${ }^{2}$ Toulmin intends his view to be literally evolutionary ("Evolutionary Development" 470-471) but not 
literally Darwinian: the variants are not traits but variant ideas; selective pressure in the intellectual world is due to "severity of criticism" ("Evolutionary Development" 471). Critical thought gives us an alternative to natural selection (Toulmin, "Human Adaptation" 192-193). Toulmin stresses that "... the continuity and change which are characteristic of an evolving intellectual tradition must be related, in any such account, to the processes of transmission by which the ideas in question are passed on from one generation of human 'carriers' to the next" ("Evolutionary Development" 459; emphasis added; see also Human Understanding 1:158-161).

This theory has been criticized because Toulmin clearly explains neither the origins of selection criteria nor what justifies them (Jacobs 522; Harpine 104-106). In other words, if an argument is justified by the selection criteria of the relevant rational enterprise, such as atomic physics, biochemistry, sociology, or anthropology, (Toulmin, Human Understanding 1:133 ff., $146,264,348$ ), what in turn justifies the enterprise's selection criteria? To Toulmin, evaluative standards are evolving concepts dependent for validity on their context ("Evolutionary Development" 465). ${ }^{3}$

Campbell offers a possible grounding for such criteria. He advocates that all human thought and behavior emerge from a "blind-variation-and-selective-retention process." Evolution requires (1) a way to produce variations, (2) predictable selection processes, and (3) a method for transmitting successful variations (Campbell, "Evolutionary Epistemology" 421). ${ }^{4}$

Campbell holds that the capacity for thought evolved by natural selection, more abstract perceptual and cognitive standards being the higher-level "inductive" developments of this process ("Evolutionary Epistemology 450-451; "Discussion" 304; Campbell and Paller, 236-237). Although there are "many processes which shortcut a more full blind-variation-and-selectiveretention process," these in turn employ blind variation and selective retention "at some level" ("Evolutionary Epistemology" 421). Thus, although scientific knowledge is usually not survival related, scienceand, presumably, other intellectual disciplines-takes advantage of cognitive abilities that were once selected for their survival value ("Evolutionary Epistemology" 450; see also Ruse, Darwinian Paradigm 223).

Campbell clearly sees the importance of culture to transmit proven intellectual variants: ". . . the trial-and-error exploration of one member of a group substitutes for, renders unnecessary, trial-and-error exploration on the part of other members" ("Evolutionary Epistemology" 431). Campbell thus argues directly for the advantages of tradition:

By sociocultural evolution we mean, at a minimum, a selective cumulation of skills. technologies, recipes, beliefs, customs, organizational structures, and the like, retained through purely social modes of transmission, rather than in the genes. Given a stability in the selective system, the cumulated culture and social system will become more and more adapted to the selective system. ("Conflict" 1104)

Contending that neither biology nor individual learning suffices to explain human behavior, Campbell insists that we must also consider the "culturally inherited baggage of dispositions, transmitted by example, indoctrination and culturally provided limitation on perspectives and opportunities. This cultural inheritance can, on evolutionary grounds, be regarded as adaptive, and treated with respect" ("Conflict" 1105). Admitting that some traditions are outmoded, Campbell nonetheless sympathizes with Lorenz's complaint that too many young people today reject time-tested ways ("Conflict" 1106; see Lorenz 61-63).

Campbell's theory has been criticized on a number of grounds, most notably for his admittedly "dogmatic" insistence that all knowledge is the product of utterly blind variation. ${ }^{5}$ Campbell himself has 
admitted that the theory is not fully worked out ("Reprise" 381). But what, other than gut instinct, leads him to call militarism an outmoded tradition but not religious tradition? For our purposes, the most important weakness of his account of tradition is that he provides no explanation of how some traditions become outmoded while others do not, nor does he provide criteria for when we should accept tradition and when we should reject it. ${ }^{6}$

\section{Cultural Tradition and Natural Selection}

\section{Cultural Inheritance}

Darwin developed his theory of natural selection and evolution without any knowledge of genetics, and so cultural evolutionists often reason that neo-Darwinian theory can work with cultural transmission (Bettinger 181). ${ }^{7}$ Many authorities recognize that culture constitutes a stable system for transmitting knowledge, ideas, and social practices. ${ }^{8}$ But through culture people also shape their environment, and those aspects of a culture over which the individual has no control become a part of the environment to which individuals must adapt. ${ }^{9}$

Boyd and Richerson explain the advantage cultural learning enjoys over individual learning:

\begin{abstract}
Variants acquired by individual learning and other common forms of phenotypic flexibility are lost with the death of the individual, and only the genes that underlie the capacity to learn are evolving properties of the population. In contrast, culturally acquired variations are transmitted from generation to generation and, like genes, they are also evolving properties of the population. (Boyd and Richerson 4)
\end{abstract}

Thus, "if the locally adaptive behavior is more common than other behaviors, imitation provides an inexpensive way to acquire

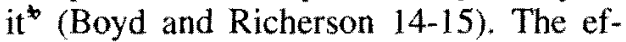
fects of cultural transmission can differ in specific, important ways from the effects of genetic transmission (Boyd and Richerson 198-199). People can transmit cultural knowledge and behaviors not only to birth children but to adopted children, friends, disciples, and students. Cultural transmission can be vertical-from one generation to the next, or horizontal-among generational peers (Boyd and Richerson 11, 178).

\section{Culture and Natural Selection}

Whatever abilities enable us to develop cultures evolved because they gave humankind a "selective advantage" (Rindos 74; see also Leakey and Lewin 190-192, 223 ). But the occurrence of a cultural variation carries no presumption that it is adaptive; selection simply weeds out unacceptable variations after they occur: ". . . if everyone acquires their behavior unselectively, there will be no force that will act to increase the frequency of adaptive traits-cultural transmission is a useful shortcut to ordinary trial-and-error learning only if some force acts to increase the frequency of favorable cultural variants" (Boyd and Richerson 80).

One such force, still, is natural selection. A culture's selections are not necessarily keyed to Darwinian success-in what possible sense could ice cream and cake, thoroughly selected by North American culture, improve survival and reproduction?-but a culture whose selections are consistently poor over time imposes competitive disadvantages on its adherents (Harris, Our Kind 127).

Cultural and natural selection operate not only on specific behavior but also on the culture's selection criteria. ${ }^{10}$ These criteria include not only analytical criticism but also judgments of what cultural variants best provide for people's comfort and satisfaction in accordance with the preferences that selection has given us.

\section{Examples: Tradition Transmitted in a Stable Environment \\ Adaptive cultural traditions can evolve in a stable or predictable environment.}


Several populations in the Mediterranean area grow and consume huge quantities of fava beans, which cause a serious illness in persons who inherit a certain genetic trait. Surprisingly, populations in which this trait appears with high frequency also eat plenty of fava beans, even though people are fully aware of the danger (Katz 133-159).

If this isn't a great tribute to human illogic, what is? For thousands of years, countless people have eaten a quite unremarkable food knowing that they are risking death.

But it turns out that the gene that causes sensitivity to fava beans also confers relative resistance to malaria and was thus naturally selected in malaria-infested areas. Unknown to the population, eating fava beans also boosts resistance to malaria. The researchers offer that eating fava beans is a culturally transmitted trait of great antiquity, that the cultural descendants of people who eat fava beans survived and reproduced in greater numbers by virtue of their resistance to malaria. Thus, a cultural trait passed down from generation to generation was naturally selected and after many generations came to dominate the population (Katz and Schall 459-476; Katz 133-159, esp. 146-155).

Or consider the time tested wisdom with which my grandparents were raised as peasants in rural Europe, of which a good bit was unsuccessfully taught to me:

Never be vain about anything.

A large family is a blessing from God.

Never miss church.

Marry someone of your own religion.

Respect authority.

Potatoes, cheese, and eggs are the best foods.

These customs were quite workable during the long centuries of feudalism. Vanity stimulates social stress in a peasant society; large families are valuable for subsistence farm work (Farb 133, 143); religion plays a crucial part in the peasant social order (Wolf 98); authorities had best be respected because they were powerful and vindictive; and the countryside and climate were such that potatoes, cheese, and eggs provided the dense population with enough food to eke out a subsistence diet. Given the limited food supply, the people faced little danger of vascular disease despite the high fat diet. For the most part the population eventually forgot why these practices existed. They became traditions.

Or consider folk medicine. While some folk cures have only a psychological effect, many turn out to have a scientific foundation (Werner 307-314); Johns reviews numerous traditional remedies and concludes that "Until the progress of scientific medicine in the last century and a half, Western medicine offered nothing superior to these remedies" (Johns 278). Yet many traditional cultures lack clear knowledge of how their medical knowledge was developed or transmitted (Johns 271). Among the Fang of Central Africa, for example, medical knowledge is justified by the expert opinion of a person who has undergone the appropriate initiation, and it is this initiation-more than the accompanying apprenticeship - that the people consider the basis of expert knowledge (Boyer 35).

Surprising, superficially unreasonable traditional practices may have unseen advantages. One example is the culturally evolved practice of clay eating. Many foods-certain potato varieties, for example - are nourishing but toxic. People who rely on these foods risk illness. Eating clay with these foods, as practiced in the mountains of Peru, detoxifies them by absorbing toxic chemicals (Johns 67, 84-100).

It is enough for the people to know that these traditions are traditions; it is needless for individual persons to run the grave risks of experimenting because their forebears have already done so for them. For such a culture, many seemingly cogent arguments against tradition might be worth barely a second thought: the odds are too great that the argument overlooks something vital. How could any ordinary sort of 
analytical decision making process be as accurate as the traditions evolved over the generations about fava beans or sacred cattle? That the work of Western experts to help traditional societies often ends in failure testifies that supremely educated, analytically-minded groups of specialists often embrace a lesser sum of knowledge than the unthinkingly transmitted traditions of an established culture (Johns 30).

\section{Examples: Tradition in an}

\section{Unstable Environment}

Cultural transmission is more flexible than genetic transmission: human beings can observe, communicate about, and promptly adopt successful experiments, rapidly adjusting their actions to new or altered environments. Cultural transmission also allows for greater variation íe.g. "eccentric" beliefs and practices; "mutation" introduced by memory lapses) than does genetic transmission (Boyd and Richerson 125; Brow 3), affording more raw material for the selection processes.

But time tested social practices and beliefs were tested in a particular environment (compare Ruse, Taking Darwin 142). We can, and should, be prepared to rethink traditions when underlying circumstances change. Suppose that the fava bean-eating countries initiate drainage and mosquito control programs that drastically reduce the incidence of malaria: the eating of fava beans would become obsolete. A modern European living on potatoes, cheese, and eggs can look forward to a stay in coronary care.

The plight of the Betsileo of Malagasy highlights the dangers of failing to change a time-tested practice when times change. The religion of this pastoral-agricultural population stresses elaborate ceremonies for the dead. These feature speechmaking combined with elaborate redistributive feasting to which hosts and guests alike contribute. Kottak comments that "[i]ronically, for people whose ceremonial life pays so much attention to the dead,
Betsileo, apparently like other Malagasy, have little to say--other than the stock informant's answer of 'custom'-about why they do what they do" (Kottak 229-259, esp. 235).

During the last century, such ceremonies provided many Betsileo peasants with their only chance to eat meat, and in some regions funeral committees checked that people contributed only what they could afford. These ceremonies nourish a large part of the population, which is beneficial for the majority. But recently, the expanding government has organized some Betsileo regions and taxes the feasts in these areas so as to redistribute income from the poor to the rich-who control the government. Sometimes the rich now contribute nothing to their own ceremonies; the poor can be driven into hopeless debt by ceremonial expenses. The new circumstances have made the traditional practice maladaptive in these regions, and continuing italthough consistent with Betsileo religious beliefs-has become harmful to a large part of the population (Kottak 257-259). The stock appeal to "custom" made perfect sense as long as the background of their economy stayed the same, but custom became less reliable in the wake of change."

\section{Evaluating an Appeal to Traditional Wisdom: Criteria}

Since it may be very difficult to analyze the underlying merits of a traditional practice, a critic might instead evaluate the cultural circumstances in which the practice was developed. One asks first how stable the environment has been and how well the culture's members function in general relative to the available resources. The tradition-bound church mentioned at the beginning of this essay had lost so many of its younger members as to be in danger of collapse, and its leaders' reluctance to improve their youth program made little sense. They may not have known what was 
wrong, but they knew that something was wrong and should have entertained doubts about their traditions. Their traditions were really only thirty years old, hardly the span of generations necessary to weed out unsound variations. And they might have noted the dramatic changes in the surrounding community: economic development, the growth of industry, and social strife, which rendered their traditions outdated.

The presumption for tradition is strongest for beliefs that affect actions and which are therefore subject to natural selection pressures. Consider Hume's famous admission that he could neither believe nor live by his own skeptical theory when away from his study: since his daily life ignored his philosophical findings, errors in his theory were beyond the reach of natural selection pressures. Also, the presumption of traditional wisdom is faulty for a culture that is poorly adapted to its environment: $:^{12}$ a population succumbing to competitive pressures should take a fresh look at its traditions.

Drift, that is, random variation, can cause a small population to wander off into sub-optimal directions or could remove rare traits. Both genetic and cultural drift can become significant evolutionary forces in small populations but generally not in large populations in which chance variations tend to even themselves out (Boyd and Richerson 9, 69; Sober 110-112). So, although drift cannot override natural selection, a critic should be aware that traditions in small populations can vary due to imprecise transmission.

Selection processes can prefer only those variations that exist for the individuals in question (Braun 81). Consider again the position of peasants, who usually live a marginal subsistence existence, whose surplus incomes are likely to be removed by rent or taxation. Since they usually live in highly stable circumstances, peasants evolve notably adaptive traditional practices from the variations that are available to them. This explains why they "tend to cleave to their traditional way of life, why they fear the new as they would fear temptation: any novelty may undermine their precarious balance;" by maintaining their internal social institutions, the "peasant community can ward off the further penetration of outside demands and pressures...." (Wolf 16-17).

Peasants must reject innovations just because they are innovations. But this does not mean that the peasant adaptation, which is often a rather miserable way of life, is the best of all possible alternatives for the peasant (although it is an excellent adaptation for the oppressor). Since peasants lack political power, the variation of not being oppressed is not available-and therefore selection processes cannot choose it. Peasants are usually very well adapted to their situation, but that does not justify the situation itself.

This leads us further to Habermas's argument that tradition can create social structures and power relationships that in turn constrain openness of argument according to relationships based on power or wealth. As it depends on egalitarianism, what Habermas calls enlightened discourse ". . . could be guaranteed only by the ideal conditions of general communication extending to the entire public and free from domination. ... The depoliticization of the mass of the population and the decline of the public realm as a political institution are components of a system of domination that tends to exclude practical questions from public discussion." 13 One must distinguish between a tradition validated by generations of testing from one maintained by dominance; it would be invalid to appeal to tradition to reject a variation that had been suppressed without testing. Similarly, it would be invalid to accept a tradition that exists solely because it was imposed by power, as such distortions might preclude the selection of adaptive variations.

But on the other hand, the practice of insulating fundamental cultural ideas from 
criticism can have its value. Munz believes that this serves a social bonding function-that it unites a culture's members to hold uniform, unquestioned beliefs (Munz, Our Knowledge 303; Munz, "Taking Darwin"). Perhaps so: but it might also insulate time-tested ideas from needless (and risky) reevaluation. Munz believes that these protected ideas are not critically evaluated, but perhaps many of them were quite thoroughly evaluated-in the forgotten past. Historical or archaeological study might reveal this. But more important is to distinguish traditions adopted by a downtrodden class to adapt to their circumstances from those imposed by those in authority to divert resources to themselves.

A stable culture's practices might be the best among those that have been tried, but new variations not tested in the past are likely to be worthy of cautious trial. Intercultural contact can be one rich source of new, perhaps desirable variations. For example, although traditional folk medicine typically preserves the best treatments from among those that a culture has discovered, the superiority of scientific medicine in treating complex diseases such as cancer is quite clear (Johns 278-279). ${ }^{14}$

\section{Conclusion}

"Never before in human history have the linkages between the environmental and social domains been less constant.
Automation, new chemicals, population growth, and a kaleidoscope of technological innovations bring change at a rate faster than ever before" (Clapham 7). The more rapid the changes, the more we must rely on experiment and on our intellectual resources. Technological society can build on its traditions, but can no longer be enslaved to them. This is what Campbell and Lorenz miss when they complain about the younger generation's lack of respect for tradition. With much of Western culture's time-tested traditional wisdom obsolete, people who experiment-even when they experiment blindly-may be acting reasonably (despite appearances). I doubt that any peoples can reject all tradition and endure, but changing circumstances suggest a need to start taking more risks.

But a more stable culture well adapted to its environment offers a meaningful albeit defeasible warranty on behalf of its traditional practices because, whether they developed by accident, by trial and error, or by careful (if long forgotten) reasoned analysis, they have been thoroughly tested by selection processes. People may reasonably stick to the tried and true: the human ability to pass traditions from generation to generation may seem non-logical but it is frequently capable of producing and retaining adaptations of considerable sophistication. Yet, on the other hand, neither should people consider themselves wise to adhere to traditions that no longer suit the changing times.

\section{Notes}

1 As suggested by, say, Warnick and Inch 135 or Kahane 60-61. Whately finds a very weak but variable presumption for existing practices and beliefs. He holds that existing beliefs and practices should be retained unless there is a reason to change them, but this does not imply to him any probability that existing institutions are right; he finds it similarly quite wrong to presume that traditions are right (Whately 112-118).
2 Toulmin makes a similar point in Human Understanding 1:355. See also Habermas's parallel discussion of this issue, Communication $171-177$.

3 Toulmin may have planned to give such an account in the remaining volumes of his unfinished Human Understanding, as hinted in his "Research Programme" in that work, 1:504 508. Toulmin is careful to distinguish his 
views from those of more relativist philosophers (Human Understanding 1:73-85) and often describes his theory as a middle way between objectivism and relativism.

4 The usual central assumptions behind the neo-Darwinian theory of natural selection include richness of variation that is spontaneous and persistent, abundant, small, continuous, and nondirected; together with a sorting mechanism that prefers variations suited to the environment (Amundson 417). Contrary to his predecessors, Darwin held that evolution did not require large, discrete, goal-directed variations. I do not read Darwin to argue that natural selection mechanisms are helpless to operate on such variations if they happen to occur (Darwin; Sober 110).

5 Evaluations of Campbell's work include Boyd and Richerson 205; Wispe and Thompson; Richards; Ruse, Taking Darwin Seriously 58 ff. I caution that not all of Campbell's critics seem to have read him very carefully -as Wispe and Thompson note.

6 A good critical summary of the extensive literature in evolutionary epistemology is Hahlweg and Hooker, "Evolutionary Epistemology." Ruse questions Toulmin and Campbell's approaches because he believes that variations in culture are not random (Taking Danwin 5865). However, not only did Darwin himself believe that acquired (and therefore non-random) traits could be inherited (Sober 109-110), but Campbell's reasoning that the processes that produce guided variations are the product of blind variation and natural selection seems telling (Campbell, "Discussion" 504). Campbell's critics seem to miss his point that much blind variation in human thought and behavior is "vicarious," i.e. purely mental, perceptual, cultural, etc. Campbell's theory of blind variation does not imply the absurd position tha! actual human conduct varies blindly.
7 Alland gives an excellent review of modern Darwinian theory applied to human beings. A good account of evolutionary theory by a philosopher is Sober; a few of his points are mildly controversial; see also Amundson. Marvin Harris argues for a more limited use of the term "adaptive" in "Cultural Ecology," p. 52, n.1. In the present essay the term refers to whatever practices and traits increase phenotypic fitness.

8 Toulmin, "Evolutionary Development" 459; Ruse, "Taking Darwin Seriously" 125; Kottak 229; Boyd and Richerson 171; Johns 20.

9 This accords with Harris's definition of environment, Our Kind 64; see also Hahlweg, "II" 61. Boyd and Richerson define environment as not created by the species (34), but many of the examples throughout their book clearly treat culture as part of the individual's environment.

10 Boyd and Richerson 11, 157; Campuell, "Discussion" 504; Campbell, "Evolutionary Epistemology", 421.

11 Evans (245-249) makes a similar point about Laos. The government reorganized the economy and ended what they felt was the wasteful capitalistic practice of redistributive feasting, which had the unintended effect of worsening economic inequality.

12 Thus, note the cautions of Harris and Ross, Afterward 597.

13 Habermas, Rational Society 75. See McCarthy ch. 1; Wenzel 83-94. Habermas discusses tradition and validity claims at length in Communication, 95-98, 152-167, 171-172.

14 One stresses caution even for scientific medicine. For example, efforts of Western physicians to overcome the widespread cultural value of Asia and Africa against milking failed in part because, unknown to physicians of the 1950 s, most of the populations of those continents are physiologically unable to tolerate lactose (see Simoons 84-89).

\section{References}

Alland, Alexander, Jr. Evolution and Human Behavior: An Introduction to Danwinian Anthropology. 2nd ed. Garden City: AnchorDoubleday, 1973.

Amundson, Ron. "The Trials and Tribulations of Selectionist Explanations:" Hahlweg and Hooker, Issues 413-432.
Bettinger, Robert L. Hunter-Gatherers: Archaeological and Evolutionary Theory. Interdisciplinary Contributions to Archaeology. New York: Plenum, 1991.

Boyd, Robert, and Peter J. Richerson. Culture and the Evolutionary Process. Chicago: University of Chicago Press, 1985. 
Boyer, Pascal. Tradition as Truth and Communication: A Cognitive Description of Traditional Discourse, Cambridge: Cambridge University Press, 1990.

Braun, David P. "Selection and Evolution in Nonhierarchical Organization." Upham 62-86.

Brow, James. "Notes on Community, Hegemony, and the Uses of the Past." Anthropological Quarterly 63 (1990):1-6.

Campbell, Donald T. "On the Conflicts Between Biological and Social Evolution and Between Psychology and Moral Tradition." American Psychologist 30 (1975): 1103-1126.

"Discussion: Comment on "The Natural Selection Model of Conceptual Evolution." Philosophy of Science 44 (1977): 501-507.

\section{1:413-463.}

"Reprise." American Psychologist 31 (1976): $381-384$

Campbell, Donald T., and Bonnie T. Paller. "Extending Evolutionary Epistemology to 'Justifying' Scientific Beliefs (A Sociological Rapprochement with a Fallibilist Perceptual Foundationalism?)." Hahlweg and Hooker, Issues 231-257.

Clapham, Jr., W. B. Human Ecosystems. New York: Macmillan, 1981.

Darwin, Charles. The Origin of Species. Everyman ed. London: JM Dent, 1928.

Evans, Grant. "'Rich Peasants' and Cooperatives in Socialist Laos." Journal of Anthropological Research 44 (1988) 229-250.

Farb, Peter. Humankind. Boston: Houghton, 1978.

Habermas, Jurgen. Communication and the Evolution of Society. Trans. Thomas McCarthy. Boston: Beacon, 1979.

Toward a Rational Society: Student Protest, Science, and Politics. Trans. Jeremy Shapiro. Boston: Beacon, 1971.

Hahlweg, Kai. "II: A Systems View of Evolution and Evolutionary Epistemology" in Hahlweg and Hooker, "Evolutionary Epistemology and the Philosophy of Science." Hahlweg and Hooker, Issues 45-78.

Hahlweg, Kai and C.A. Hooker. "Evolutionary Epistemology and Philosophy of Science." Hahlweg and Hooker, Issues 21-151. eds. Issues in Evolutionary Epistemology, Albany: SUNY Press, 1989.

Harpine, William D. "Can Rhetoric and Dialectic Serve the Purposes of Logic?" Philosophy and Rhetoric 18 (1985): 96-112.

Harris, Marvin. Cows, Pigs, Wars \& Witches: The Riddles of Culture. New York: Random, 1974.

. "The Cultural Ecology of India's Sacred Cattle." Current Anthropology 7 (1966): 51-59.

Our Kind: Who We Are, Where We Came From, Where We Are Going. New York: Harper, 1989.

Harris, Marvin, and Eric B. Ross. Afterword. Harris and Ross, Food and Evolution 595-597. , eds. Food and Evolution: Toward a Theory of Human Food Habits. Philadelphia: Temple University Press, 1987.

Jacobs, Struan. "Stephen Toulmin's Theory of Conceptual Evolution." Hahlweg and Hooker, Issues 510-523.

Jensen, U.J., and R. Harre. The Philosophy of Evolution. New York: St. Martin's, 1981.

Johns, Timothy. With Bitter Herbs They Shall Eat It: Chemical Ecology and the Origins of Human Diet and Medicine. Tucson: University of Arizona Press, 1990.

Kahane, Howard. Logic and Contemporary Rhetoric: The Use of Reason in Everyday Life. 6th ed. Belmont, Ca.: Wadsworth, 1992.

Katz, Solomon H. "Fava Bean Consumption: A Case for the Co-Evolution of Genes and Culture." Harris and Ross, food and Evolution 133-159.

Katz, S. H. and J. Schall. "Fava Bean Consumption and Biocultural Evolution." Medical Anthropology 3 (1979): 459-476.

Kottak, Conrad Phillip. "The Material Conditions of Variation in Betsileo Ceremonial Life." Ross 229-259.

Leakey, Richard E. and Roger Lewin. Origins: What New Discoveries Reveal About the Emergence of Our Species and Its Possible Future. New York: Dutton, 1977.

Lorenz, Konrad. Civilized Man's Eight Deadly Sins. Trans. Marjorie Kerr Wilson. New York: Harcourt-A Helen and Kurt Wolff Book, 1973. 
McCarthy, Thomas. The Critical Theory of Jurgen Habermas. Cambridge: MIT Press, 1978.

Minturn, Robert B. From New York to Delhi, by Way of Rio de Janeiro, Australia and China. 3rd ed. New York: Appleton, 1859.

Munz, Peter. Our Knowledge of the Growth of Knowledge: Popper or Wittgenstein? London: Routledge, 1985.

. "Taking Darwin Even More Seriously." Halweg and Hooker, Issues 278-293.

Nair, K.N. "Animal Protein Consumption and the Sacred Cow Complex in India." Harris and Ross, Food and Evolution 445-454.

Poggie, Jr., John J. Gretel H. Pelto, and Pertti J. Pelto. The Evolution of Human Adaptations: Readings in Anthropology. New York: Macmillan, 1976.

Richards, Robert J. "Discussion: The Natural Selection Model of Conceptual Evolution." Philosophy of Science 44 (1977): 494-501.

Rindos, David. "Darwinian Selection, Symbolic Variation, and the Evolution of Culture." Current Anthropology 26 (1985): 65-77.

Ross, Eric B., ed. Beyond the Myths of Culture: Essays in Cultural Materialism. New York: Academic, 1980.

Ruse, Michael. The Darwinian Paradigm: Essays on its History, Philosophy, and Religious Implications. London: Routledge, 1989.

Taking Darwin Seriously: A Naturalistic Approach to Philosophy. Oxford: Basil Blackwell, 1986.

Schilpp, Paul Arthur, ed. The Philosophy of Karl Popper. 2 vols. Library of Living Philosophers 14. LaSalle, Ill. Open Court, 1974.

Simoons, Frederick J. "The Determinants of Dairying and Milk Use in the Old World: Ecological, Physiological, and Cultural." Food, Ecology and Culture: Readings in the Anthropology of Dietary Practices. J.R.K. Robson, ed. New York: Gordon and Breach, 1980. 83-91.
Sober, Elliott. The Nature of Selection: Evolutionary Theory in Philosophical Focus. Cambridge, Mass.: MIT-Bradford, 1984.

Toulmin, Stephen E. "The Evolutionary Development of Natural Science." American Scientist 55 (1967): 456-471.

"Human Adaptation." Jensen and Harre 176-195.

Human Understanding. 1 vol, to date. Princeton, NJ: Princeton University Press, 1972.

Upham, Steadman, ed. The Evolution of Political Systems: Sociopolitics in Small-Scale Sedentary Societies. School of American Research Advanced Seminar Series. Cambridge: Cambridge University Press, 1990.

Warnick, Barbara and Edward S. Inch. Critical Thinking and Communication: The Use of Reason in Argument. New York: Macmillan, 1989.

Wenzel, Joseph W. "Jurgen Habermas and the Dialectical Perspective on Argumentation." Journal of the American Forensic Association 16 (1979), 83-94.

Werner, David. "Healing in the Sierra Madre." Poggie, Pelto, and Pelto 307-314.

Whately, Richard. Elements of Rhetoric: Comprising an Analysis of the Laws of Moral Evidence and of Persuasion, with Rules for Argumentative Composition and Elocution. Ed. Douglas Ehninger. Carbondale: Southern Illinois University Press, 1963 (orig. 1828).

Wispe, Lauren G. and James N. Thompson, Jr. "The War Between the Words: Biological Versus Social Evolution and Some Related Issues." American Psychologist 31 (1976): 341-347.

Wolf, Eric R. Peasants. Englewood Cliffs: Prentice, 1966.

WILLIAM D. HARPINE

SCHOOL OF COMMUNICATION

UNIVERSITY OF AKRON

$A K R O N, O H 44325-1003$ 